\title{
A terra, A tela e A letrA
}

Susanna Busato

UNESP - São José do Rio Preto

\begin{abstract}
RESUMO
Este estudo visa elaborar uma leitura dos aspectos semióticos que organizam os espaços de significação no processo da formação cultural brasileira a partir dos processos tradutórios realizados por parte das expedições exploratórias que para os trópicos vieram. Investigam-se, assim, por meio de relações em nível paradigmático e sintagmático, as produções pictóricas dos artistas viajantes dos séculos XVII, Albert Eckhout e Frans Post, e as produções poéticas barrocas de Gregório de Matos, Manuel Botelho de Oliveira e Manuel de Santa Maria Itaparica.
\end{abstract}

\section{P A L A VRAS - CHAVE}

Representações pictóricas e poéticas do Brasil, o olhar europeu, tradução cultural, Barroco

Da terra, à tela e à letra, o olhar do homem europeu nos Trópicos inaugura um universo de representação que se impõe segundo zonas de tensão entre o centro ideológico da cultura de onde parte (a Europa) e a periferia a que chega (os trópicos). A perspectiva do olhar europeu para com os Trópicos está centrada numa memória mítica do mundo recuperada pela linguagem dos artistas viajantes, que procuram dar sentido aos signos que apreendem do espaço novo que adentram. Os meios de sincronizar os tempos e espaços flagrados no contato sensível com a terra e deslindá-los pela memória acionada ainda aqui ou lá, em seu país de origem, como no caso dos artistas viajantes e dos poetas que aqui produziram seus versos e representaram a terra, são objeto de reflexão deste texto que se tece indagando sobre as relações entre o espaço semiótico construído pela tela dos artistas viajantes e pela letra dos poetas.

Expressar o mundo por meio de sinais de qualquer natureza é uma ação que permeia a história humana e lhe dá caráter histórico. No processo de construção do seu olhar, o homem age como um tradutor ao representar os modelos que percebe no espaço. Sua representação é permeada pelo código, pelo sistema de sinais de que se vale para criar em forma de linguagem seu olhar sobre as coisas. A cultura, segundo Yuri Lotman, caracteriza-se por ser um sistema de signos, de informações que são transmitidas por herança (dispositivo da memória) e transformadas por meio de novas formas sígnicas, que podem tanto reforçar como se opor àquelas. Sendo assim, o papel da cultura seria "organizar estruturalmente o mundo que rodeia o homem", ${ }^{1}$ tornando possível o

${ }^{1}$ LOTMAN. Semiótica de la cultura, p. 70. 
estabelecimento das relações sociais, humanas e lingüísticas. Em termos da formação cultural e histórica brasileiras, os processos tradutórios por parte das expedições exploratórias, por exemplo, que para cá vieram, deram-se de forma progressiva e pouco linear, uma vez que os paradigmas que leram nossa paisagem e etnia foram obrigados a repensar a si mesmos e a se deixar invadir por uma nova configuração plástica - a paisagem, o homem e a cultura que nos Trópicos havia.

A produção poética de Gregório de Matos (1636-1696), Botelho de Oliveira (16361711) e Manuel de Santa Maria Itaparica (1704-?), poetas brasileiros que escreveram em muitos de seus versos referências ao Brasil, sua paisagem e costumes (como no caso de Gregório de Matos, que criou, além de poemas religiosos e lírico-amorosos, críticas ao comportamento de governantes, freiras, frades, por exemplo, e ao aspecto econômico e social de sua época), insere-se na tradição estética barroca. Ao representar seu olhar sobre o Brasil, os sujeitos poéticos trazem de forma ambígua o tom superlativo e exuberante da composição, cujos referentes, plasticamente, ocupam um espaço que oscila entre o próximo e o distante, ou seja, entre a marca daquele que vê de dentro a paisagem e a expressa com um olhar de fora, deslumbrado, de quem contempla o interno. Essa marca, ainda que balizadora de um olhar sobre o Brasil, é construída por uma convenção externa, importada, uma convenção que lê o homem, a paisagem e a cultura e lhe dá caráter estético, integrando-se, paradoxalmente, aos modos de ler os Trópicos como estranhos e exóticos, selvagens e paradisíacos.

Ao refletir sobre os relatos de Auguste de Saint-Hilaire sobre várias províncias, distritos e comarcas do reinado português, Marco Pereira e Francine Iegelski, no artigo intitulado "O paraíso terrestre no Brasil: os Campos Gerais do Paraná no relato de Auguste de Saint-Hilaire", afirmam que:

O olhar sobre e a descrição do outro não são construídos a partir da especificidade da outra cultura, a cultura brasileira, interpretada a partir de si mesma, dos seus próprios signos e significados. São, sim, elaborados a partir dos valores, da lógica e da visão de mundo européia do autor. ${ }^{2}$

Tal afirmação leva-nos a pensar que, no processo de formação da cultura brasileira, o olhar do estrangeiro, em termos da sua presença nos Trópicos e em termos de uma linguagem esteticamente elaborada que chega aos Trópicos em meio às suas malas, colabora para a construção de nossa identidade, na qual se dará a síntese dialética do encontro entre as culturas por meio dos traços dos pintores que constituirão aos poucos um fazer artístico no Novo Mundo, por meio das academias de belas artes, e por meio da letra dos poetas, que construirão o tom e o ritmo próprios de um fazer poético que se consolidará como nacional ao longo dos séculos seguintes.

Perpassa as produções tanto literárias quanto pictóricas um discurso mítico, fundamentado nas narrativas maravilhosas dos primeiros viajantes aos Trópicos. As fronteiras entre o real e o imaginário surgiam tênues para os primeiros navegadores e muitos dos relatos continham passagens descritivas de monstros e criaturas de natureza demoníaca, calcadas nas imagens de origem medieval que ainda permaneciam no imaginário do homem europeu.

${ }^{2}$ PEREIRA; IEGELSKI. O paraíso terrestre, p. 51. 
O estudo da construção do imaginário medieval presente na literatura de viajantes e nas iconografias da época é parte significativa de um universo cultural e de uma concepção de mundo que se construiu a partir do material documental que a cultura européia nos legou. [...] trata-se das tradições do pensamento da Idade Média que ultrapassaram o Atlântico e chegaram ao Novo Mundo por meio dos viajantes. ${ }^{3}$

Quando percebemos que nos versos de Gregório de Matos, Botelho de Oliveira e Santa Maria Itaparica transparece um olhar estrangeiro, ao descrever do ponto de vista interno da paisagem um universo encantado, um paraíso tropical, podemos considerar que a perspectiva da voz desses poetas parte de um discurso poético já convencionado segundo as leis estéticas da poesia barroca, cujo influxo para o deslumbramento e artificialização são procedimentos que constroem o gosto poético e correspondem ao universo de leitura de sua época. A presença, por exemplo, de figuras da mitologia greco-romana nos poemas, de modo a alegorizar a paisagem, era um recurso comum e participava do universo semiótico do homem dos seiscentos e setecentos. $O$ fato de esses poetas retratarem com sensibilidade a paisagem tropical pela linguagem, tornando-a expressão, aponta para um caminho estético e filosófico de busca pela verdade (o vir-a-ser, a identidade) de um mundo ainda percebido em estado primitivo, não-cultural, fora das convenções do homem civilizado, europeu, que era o paradigma dos poetas nesse período.

Ao observarmos as pinturas que Albert Eckhout (1610-1665) ${ }^{4}$ e Frans Post (1612$1680)^{5}$ fizeram da paisagem, etnia e flora tropicais, por exemplo, perceberemos que revelam o encontro dialógico entre o olho, a paisagem e a cultura flagrada pela retina da memória das narrativas maravilhosas sobre os trópicos e pela retina do olhar maravilhado e submetido à função de documentar o Novo Mundo. A representação simbólica dos elementos étnicos deixa transparecer um olhar preocupado com os detalhes dos seres, dos trajes, dos comportamentos e da culinária, reunidos num só espaço recortado pela composição acadêmica ${ }^{6}$ das linhas e perspectiva, para servir de referência a uma cultura selvagem e exótica, hostil e desejada.

É com o olhar deslumbrado e ao mesmo tempo receoso que as linhas fortes e robustas dos legumes, raízes e frutas das telas de Albert Eckhout sincronizam a exuberância das maravilhas tropicais. O espaço que as figuras na tela ocupam é reduzido, pois aparentemente estão dispostas sobre uma mesa ou patamar de janela, cuja parte superior apenas se deixa entrever. Ao fundo, um céu que simboliza o ambiente externo em que as figuras se situam, deixando assim assinalar seu caráter selvagem, rústico e primitivo.

\footnotetext{
${ }^{3}$ GIMENEZ. A presença do imaginário medieval no Brasil colonial, p. 208.

${ }^{4}$ Albert Eckhout, pintor e desenhista, integrante da comitiva do conde João Maurício de NassauSiegen, pela Companhia das Índias Ocidentais, em 1637, com a função de estudar e documentar a fauna e flora dos trópicos, bem como os tipos humanos da terra e sua topografia.

${ }^{5}$ Frans Post, pintor, desenhista e gravador, que integrou a comitiva de Maurício de Nassau, entre 1637 a 1644, tendo como função documentar os portos e edificações, civis e militares, assim como a paisagem. Considerado o "primeiro pintor da paisagem brasileira como também o primeiro paisagista das Américas". (LAGO. Mostra do redescobrimento.)

6 "A estética renascentista havia desenvolvido na Europa o gosto por uma representação que trabalhava a coincidência, a reprodução da realidade como arte. A arte renascentista, ao querer reproduzir, impôs um padrão que deveria nortear a obra da conquista. A América deveria constituir-se à imagem e semelhança da Europa." (THEODORO. América Barroca, p. 121.)
} 
O quadro de Albert Eckhout intitulado Abacaxi, melancias, e outras frutas (Fig. 1), a que me refiro em particular, faz parte de um conjunto de doze telas de naturezasmortas, com representações de flores, frutos, peixes e animais de caça, que se encontram atualmente no Museu Nacional da Dinamarca.

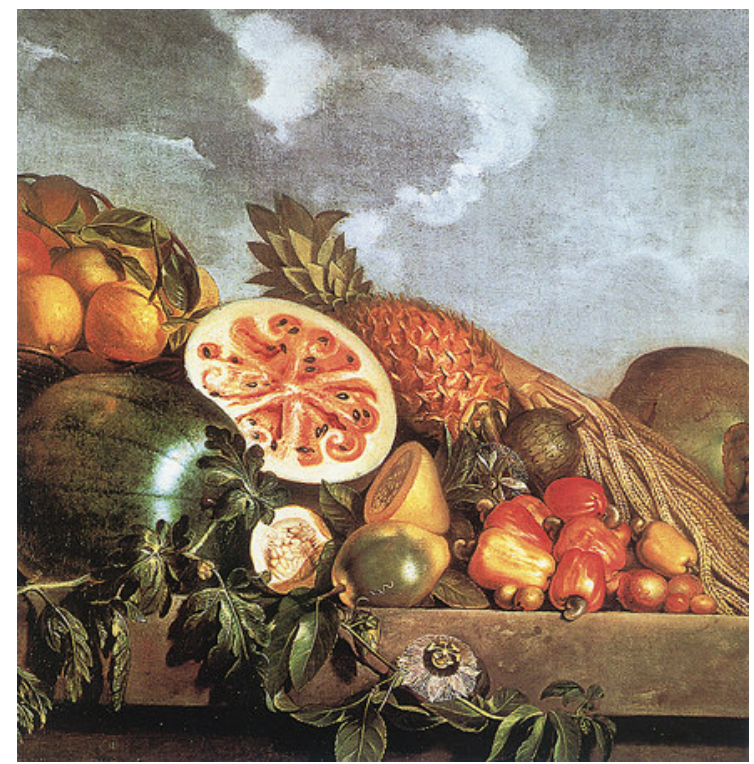

Fig. 1: Albert Eckhout (1610-1665), Abacaxi, melancias e outras frutas, s.d. Óleo sobre tela, 91 x $91 \mathrm{~cm}$. Copenhague: Nationalmuseet. Cf. Prancha 8, p. 380.

A pintura realizada pelos artistas holandeses traz muito do elemento natural, realista, com que a pintura holandesa no século XVII se caracterizou por meio de seus motivos domésticos, cenas do cotidiano, naturezas-mortas, retratos e paisagens. Muito embora o barroco italiano florescesse na Europa, os artistas holandeses desenvolveram

um estilo sóbrio, realista, comprometido com a descrição de cenas rotineiras, de temas da vida diária, de homens dedicados a seus ofícios, de mulheres no interior da casa e de festas comunitárias, no campo e na cidade. As imagens caracterizam-se, em geral, pela riqueza de detalhes, pela precisão e apuro técnico, numa tentativa de registro fiel do que o olho humano é capaz de captar. ${ }^{7}$

O artístico da composição destaca os pintores holandeses, sobretudo Albert Eckhout e Frans Post, de outros artistas viajantes que, sendo naturalistas e/ou botânicos, apenas registravam os espécimes vegetais e animais em desenhos ricos de detalhes para estudo posterior e catalogação da flora e fauna tropicais.

A série de quadros que descrevem a flora tropical faz parte do gênero naturezamorta. Tal gênero funciona pelo recorte de elementos que partem da natureza, ou, pelo menos, tem como referência a natureza, o mundo tal qual é dado à percepção. A representação dessas figuras estaria no plano do ideal, uma vez que partem do mundo natural, com o qual mantêm uma analogia. A representação das frutas tropicais (melancia, coco, caju, laranja, maracujá e abacaxi) mostra-se realista no traço e no volume. As cores fornecem voluptuosidade pelo naturalismo que situa a representação no nível da perfeição dos detalhes externos e internos das frutas. A impressionante majestade apresentada pelo primeiro plano em que as figuras estão dispostas revela o

\footnotetext{
${ }^{7}$ www.itaucultural.org.br. Enciclopédia Itaú Cultural de Artes Plásticas. Verbete pintura holandesa.
} 
teor de importância dado ao motivo tropical. Todas as figuras de frutas têm seu lugar no espaço e todas se exibem com o mesmo valor. A composição do quadro é descritiva e sugere um sujeito observador que se posiciona, pela contemplação da beleza dos motivos e pela participação sugerida por meio do majestoso primeiro plano, dentro do quadro.

Pela intenção do artista, o referente do mundo externo adentra o mundo da representação, balizado por um gênero pictórico estranho ao paradigma do contexto não-textual, da não-cultura, que é o espaço dos Trópicos para o europeu. É o olhar deste último que, munido do instrumental de sua cultura, da qual parte como modelo de visão, flagra o elemento novo e absorve-o, deformando-o, pela representação pictórica. O processo de découpage realizado constrói uma imagem sobre o já visto, imagem na qual se reconhecem os elementos em relação e, ao mesmo tempo, percebidos como estranhos porque deslocados de seu ambiente natural e expostos numa ilusão dos sentidos, revelada pelos volumes dos desenhos das frutas, que refletem a luz por um movimento descontínuo e sedutor dos olhares. Nesse caso, a composição passa do aspecto ilusionista para o da convenção. É o olhar estrangeiro, o gênero natureza-morta, realizado pelo artista viajante, que representa a paisagem tropical e lhe dá caráter estético. Em outras palavras, essa representação poderia ser entendida como "domesticação" do estranho, colocado numa configuração pictórica aceita pela convenção e concebida como janela ${ }^{8}$ para olhar o Novo Mundo: um mundo selvagem, mas obediente, por um lado, aos critérios da cultura que o lê e o (de)forma para a Europa, embora, por outro lado, extremamente hostil ao dar a resposta negativa à chegada do estrangeiro. ${ }^{9}$

No quadro de Eckhout, em primeiro plano, as figuras são detalhadas em seu interior e superfície e eroticamente dispostas na linha horizontal e na ascendência diagonal na tela, como que deitadas e lânguidas ao olhar do outro que, despudoradamente, passeia pelas dobras e reentrâncias das delícias da terra. Não seria cedo afirmar que, com essa mesma metáfora do gozo, Botelho de Oliveira (1631-1711) iniciará seu poema heróico "A Ilha de Maré":

Jaz em oblíqua forma e prolongada

A terra de Maré toda cercada

De Netuno, que tendo o amor constante,

Lhe dá muitos abraços por amante,

E botando-lhe os braços dentro dela

A pretende gozar, por ser mui bela.

\footnotetext{
${ }^{8}$ A sugestão da "janela" como o lugar no qual as figuras estão dispostas encontra aqui um argumento na concepção metalingüística do quadro que se coloca como documento-relato do Novo Mundo para a Europa. Adequar o estranho ao já-visto é o dispositivo que irá construir uma idéia de Trópico para o Mundo a que pertence o artista.

${ }^{9}$ O Novo Mundo ainda era um lugar que causava espanto, deslumbramento, e também ojeriza e hostilidade por parte do europeu. O encanto da natureza convivia com o desencanto dos obstáculos naturais (com animais peçonhentos, clima diverso e nativos hostis, que muitas vezes praticavam o canibalismo): "Mesmo um animal irracional raramente devora os seus semelhantes, por que então um homem iria devorar os outros?" (STADEN. A verdadeira história dos selvagens, nus, ferozes devoradores de homens, p. 106); "Entretanto, no que concerne a esta gente que, conforme por diversas vezes falamos, vive sem fé e sem lei, tal atitude [ritual de canibalismo] não é de toda estranha". (THEVET. As singularidades da França Antártica, p. 135).
} 
A plasticidade das linhas ("Jaz em oblíqua forma e prolongada"), além da alegoria construída por meio de elementos da mitologia greco-latina, promove o mesmo encadeamento de imagens de erotismo com que o Novo Mundo sempre foi descrito. $\mathrm{O}$ Belo aqui estaria justamente na intersecção entre o exótico e a linguagem de teor sublime da convenção estética, em que as imagens criam a ilusão e, consequentemente, o encantamento que não esgota o referente, mas o re-significa. $\mathrm{O}$ espaço poético seria esse espaço de aproximação entre o novo, estranho, e a linguagem que o lê. Nesse espaço se engendrariam as formas da percepção que criariam, para o gosto da época, um produto cultural que estaria de acordo com as expectativas do público.

A diagonalidade do traço, no quadro de que trato aqui, movimenta a sensibilidade do receptor para uma "erisão dos sentidos", elemento participante da estética barroca que, além de inserir-se como código que lê o Novo Mundo pela letra dos poetas, será o modo como o sujeito se posicionará diante das tensões entre um aqui e lá, entre o sentimento ambíguo de deslumbramento e o de hostilização, presentes, por exemplo, na atitude heróica dos missionários jesuítas em catequisar os gentios, ação que na "Carta" Pero Vaz de Caminha já assinalara: "[...] o melhor fruto, que dela se pode tirar, me parece será salvar essa gente. E essa deve ser a principal semente que Vossa Alteza deve nela lançar". ${ }^{10}$

Será com o mesmo descompromissado olhar para com as formas pudicas de descrever essa mesma terra que Gregório de Matos construirá sua descrição da Ilha de Itaparica:
Ilha de Itaparica, alvas areias,
Alegres praias, frescas, deleitosas,
Ricos polvos, lagostas deliciosas,
Farta de Putas, rica de baleias.
As Putas, tais ou quais, não são más preias,
Pícaras, ledas, brandas, carinhosas,
Para o jantar as carnes saborosas,
O pescado excelente para as ceias.
O melão de ouro, a fresca melancia,
Que vem no tempo, em que aos mortais abrasa
$\mathrm{O}$ sol inquisidor de tanto oiteiro.
A costa, que o imita na ardentia,
E sobretudo a rica e nobre casa
Do nosso capitão Luís Carneiro.

A eroticidade da Ilha é recuperada pelas imagens que permeiam visual e sonoramente todo o poema. A primeira estrofe, por exemplo, configura em justaposição os elementos que constroem a paisagem por meio dos motivos marinhos estruturados lingüisticamente por substantivos + locução/adjetivos: "Ilha", "areias", "praias”, "polvos”, "lagostas", "Putas", "baleias”; “de Itaparica”, “alvas”, “alegres”, “frescas”, “deleitosas”, "ricos”, “deliciosas”, "farta”, rica”. Os adjetivos participam de um olhar eufórico, deslumbrado, positivo, que acentua a robustez e a protuberância da paisagem. Os signos enumeram-se, promovendo uma gradação no plano expressivo da descrição, que parte de um olhar objetivo para promover ao final a plasmação da subjetividade do sujeito frente à paisagem.

${ }^{10}$ CAMINHA. Carta a El-Rei D. Manuel sobre o achamento do Brasil, p. 23. 
$\mathrm{O}$ arredondamento sonoro e visual das vogais une-se à conotação erótica da sibilante /s/. O ritmo ao longo dos versos constrói uma linguagem dos prazeres que a Ilha proporciona. Esse ritmo ondulante e erótico (por meio da assonância das vogais e da conjunção com a ascendência fônica da lateral /l/) vai-se construindo junto à semântica dos termos como, por exemplo, em "baleias" (1 $1^{\text {a }}$ estrofe, $4^{\circ}$. verso), analogicamente relacionado a "mulher gorda", associado aos adjetivos "farta" e "rica" (no mesmo verso). A imagem exuberante é reforçada na $2^{\text {a }}$. estrofe, $3^{\circ}$ e $4^{\circ}$ versos: "Para o jantar as carnes saborosas, / O pescado excelente para as ceias."

O olhar em primeiro plano das telas de Albert Eckhout encontra aqui, no poema de Gregório de Matos, o diálogo necessário para a construção de um código eminentemente barroco que se alimenta das imagens tropicais, traduzindo-as para o contexto da dualidade sedutora que vive o homem dos seiscentos, alojado na tensão carne e espírito, civilização e barbárie, zonas que se mesclam a sua cultura, que oscila entre as festividades profanas da praça pública e os rituais sagrados da Igreja, que apenas reproduzem o canibalismo instintivo dos sentidos (vide o ritual da eucaristia, em que se sacraliza a devoração do outro como ritual de purificação).

Nos tercetos, Gregório de Matos polarizará a sensualidade da paisagem nas formas femininas sugeridas em "melão de ouro" e "fresca melancia", cujas formas solares e abertas metaforizam o olhar de deslumbramento que fundamentou o tópos da reflexão européia sobre os países tropicais. ${ }^{11} \mathrm{O}$ meio tropical, para o viajante europeu, torna-se objeto de enlevo e admiração, ao mesmo tempo em que é signo da nostalgia dos padrões europeus de sociedade e cultura, permitindo-lhe "recolher-se espiritualmente, de modo a recordar a pátria, do outro lado do oceano". ${ }^{12}$ Essa confluência de paradigmas inaugurou um espaço de cultura que tem no barroco um elo que lê de forma simultânea os códigos e sistemas que perfazem uma sintaxe combinatória complexa. Não se pode falar em influências neste caso, uma vez que o espaço já existente - os trópicos - é o palco de um teatro de signos plurais a medir tensões em redes paradigmáticas e sintagmáticas. Para o europeu, a visão dos trópicos realiza, do ponto de vista simbólico, "um alargamento das fronteiras do visível e um deslocamento das fronteiras do invisível”, como assinala Chauí. ${ }^{13}$ Por isso, compreendem-se as produções artísticas que tiveram como tema e objeto os trópicos como "invenções", "representações", construções culturais ${ }^{14}$ que se processaram de forma pouco linear, sem projeto, ao sabor das pertinências econômicas,

\footnotetext{
${ }^{11}$ Sérgio Buarque de Holanda, em Visão do Paraíso, irá afirmar a analogia do Paraíso Terrestre com as terras brasileiras no pensamento dos portugueses: "Sensíveis, muito embora, às louçanias e gentilezas dos mundos remotos que a eles se vão desvendando, pode-se dizer, no entanto, que ao menos no caso do Brasil, escassamente contribuíram para a formação dos chamados mitos da conquista. A atmosfera mágica de que se envolvem para o europeu, desde o começo, as novas terras descobertas, parece assim rarefazer-se à medida que penetramos a América lusitana. E é quando muito à guisa de metáfora, que o enlevo ante a vegetação sempre verde, o colorido, variedade e estranheza da fauna, a bondade dos ares, a simplicidade e inocência das gentes [...] pode sugerir-lhes a imagem do Paraíso Terrestre”. HOLANDA. Visão do Paraíso, p.7.

${ }^{12}$ VENTURA. País tropical, p. 31.

${ }^{13}$ CHAUÍ. Brasil, p. 58.

${ }^{14}$ CHAUÍ. Brasil, p. 57.
} 
políticas e religiosas, cada uma a seu tempo e com seus vetores de força. Inaugura-se um novo tempo e espaço pela tela e pela letra.

Referir-se, então, a uma prática expressiva que se origina na apreensão do outro, ou melhor, no contato com o outro, gerando o encontro dialógico entre o universo de sinais dos sujeitos envolvidos e o universo de sinais do contexto percebido, talvez seja o viés pelo qual se possa compreender o trânsito entre culturas que se deu na América Latina. Não se pode ainda compreender, aqui, o fato cultural enquanto resultado de uma cultura autóctone em contato com, e submetida à, cultura do colonizador. Essa binariedade precisa ser revista, uma vez que os processos civilizatórios no continente latino-americano implicam, como afirma Lezama Lima, "una arribada de confluências". Essas confluências são marcadas pelas trocas que tiveram como cenário a paisagem nativa, a oralidade dos sabores das frutas, os modos de interação entre os sujeitos, seus rituais e valores, selvagemente absorvidos e representados pelos produtos artísticos que estabeleceram a síntese dialética entre o eu e o outro.

Em termos da expressão dessa síntese de paradigmas, a linguagem, segundo Lotman, teria o poder de representar o mundo das coisas e dos fenômenos da sociedade, uma vez que "obriga os homens a interpretar como estruturas fenômenos cuja estruturalidade, no melhor dos casos, não é evidente". ${ }^{15}$

É por meio da linguagem que o homem pensa e expressa o mundo que habita. Os processos tradutórios, de inclusão e exclusão, de acomodação e ruptura, presidem o olhar do sujeito que opera lingüística e semioticamente o mundo dos sinais que se estrutura mediante sua ação sobre o meio. Olhar o mundo é um processo interpretativo e tradutório no sentido de que esse sujeito procura estabelecer pontos de contato entre as estruturas que percebe e as que habitam sua consciência. É dentro desse movimento perceptivo que os fenômenos culturais são constituídos; sua revivescência ou morte é determinada pelo maior ou menor grau de trânsito, de troca de informações entre sujeito e objeto. A cultura é, pois, um dado semiótico que se manifesta no sujeito, por meio de suas práticas sociais.

A plurivocidade desse elemento que empresta identidade aos sujeitos de um mesmo âmbito lingüístico favorece o intercâmbio entre essas práticas culturais e desafia aquele que procura "traduzir" o estranho para seu próprio código lingüístico-cultural.

Essa tradução é realizada pela arte por meio de um procedimento mimético que mobilizará o código do leitor, sujeito que representa / descreve a paisagem. O poema "Ilha de Maré", de Manuel Botelho de Oliveira, já citado anteriormente, recortará por um olhar objetivo elementos da flora tropical e representá-los-á, pela ótica do deslumbramento (ótica que permeia o olhar estrangeiro do viajante), cuja percepção das formas e das cores é dada pelo encontro com o objeto e pelos paradigmas que reconhecerão esses mesmo objetos. Como afirma Edgar Morin: "A percepção das formas e das cores, a identificação dos objetos e dos seres, obedecem à conjunção de esquemas inatos de esquemas culturais de reconhecimento". ${ }^{16}$ Ocorre, no processo de percepção, um movimento de devoração. O poema de Botelho de Oliveira faz a leitura da paisagem pelo código de um sistema modelizante secundário - o código poético do barroco europeu

\footnotetext{
${ }^{15}$ LOTMAN. Semiótica de la cultura, p. 70.

${ }^{16}$ MORIN. La méthode 4, p. 119.
} 
- que corresponde a uma estrutura marcada pelo simbólico. No excerto citado neste artigo, referente à primeira estrofe do poema, a linguagem busca, pelo viés da alegoria, construir uma imagem simbólica da sensualidade e erotismo que estão presentes na ótica do estrangeiro frente aos trópicos. A referência a Netuno, deus dos oceanos, personifica o viajante que se encontra com a terra - "de Maré", elemento feminino que irá completar a imagem do encontro dos amantes - a terra, selvagem e virgem; o viajante, o estrangeiro, civilizado e explorador. É desse encontro que nasce a explicação para o nome - "Ilha de Maré" - relação analógica com o mar, Netuno - que "tanto a senhoreia, / E tanto a galanteia, / Que, do mar, de Maré, tem o apelido, / Como quem preza o amor de seu querido://" Referência ao sistema de vassalagem que está no interior do sentido da imagem de subserviência que se constrói desde a primeira estrofe no delineamento da geometria dos traços do elemento feminino que sensualmente aguarda/agrada o/ao estrangeiro: "Jaz em oblíqua forma e prolongada / A terra de Maré toda cercada / De Netuno, que tendo o amor constante, / Lhe dá muitos abraços por amante/".

O modo como o código poético nessa época devora a paisagem traz um gesto civilizatório e uma intenção acalentadora das imagens oníricas que percorrem as narrativas míticas de terras aprazíveis no clima e exuberantes e férteis na sua natureza. O gesto civilizatório está na construção da linguagem barroca que lê a paisagem e que a "deforma" por ação dos símiles e das metáforas que se constroem no jogo onírico plasmador do outro: "Vereis os Ananases, / Que para Rei das fruitas são capazes;/ Vestem-se de escarlata / Com majestade grata, / Que para ter do Império a gravidade / Logram da croa verde a majestade; / Mas quando têm a croa levantada / De picantes espinhos adornada, / Nos mostram que entre Reis, entre Rainhas / Não há croa no Mundo sem espinhas./"

É certo que o poema de Botelho de Oliveira é um discorrer extenso e "regalado" que apenas exponencia positivamente os valores da terra (entre frutas e legumes). A exaltação da terra encobre o presente de miséria e de exploração a que se vê sujeitada a economia da colônia. $\mathrm{O}$ discurso é ornamentado e serve a um propósito político. Ao enaltecer a terra tropical - a Ilha de Maré - a cidade da Bahia, o poeta revela um saber de fora para dentro, um olhar deslumbrado e estrangeiro, de turista, que apenas fotografa aquilo que manipula e arranja defronte à lente de sua câmera. Por mais objetiva que possa ser a direção do foco, não há como não perceber a crônica dos viajantes sobreposta e disseminada no discurso do poema. O lógos que organiza o discurso é o da cultura estrangeira que semanticamente articula as imagens; é o olhar barroco que tem como objetivo suscitar no outro "o enlevo dos olhos, o embevecimento arrebatador e total dos sentidos". ${ }^{17}$ É esse olhar que inaugura um discurso de caráter alegórico que será reproduzido, exponenciado e fomentado pelas instâncias nacionalistas ao longo dos séculos, por meio dos produtos artísticos. ${ }^{18}$

\footnotetext{
${ }^{17}$ ÁVILA. O lúdico e as projeções do barroco, p. 197.

${ }^{18}$ Como exemplos (para ficar somente nesses) desse discurso exaltativo que procura identificar a pátria, o sentimento nacional, com as belezas da natureza, cito a "Canção do Exílio", de Gonçalves Dias; o "Hino Nacional Brasileiro", que recupera uma estrofe de Dias, a "Aquarela do Brasil", de Ari Barroso, produzida durante o Estado Novo e considerada um "hino nacional"; "País Tropical", de Jorge Ben, sucesso durante o final da década de 60; "Eu te amo meu Brasil", de Don e Ravel, que virou sucesso por sua melodia fácil e enaltecedora da letra que reproduz os estereótipos de pátria = natureza, sensualidade e beleza.
} 
Os trópicos são revelados pelos signos analógicos do discurso dominante em produções marcadas pela ótica do deslumbramento. Os signos digitais, antitéticos, da paisagem primitiva posta em trama desafiam o academicismo dos traços dos pintores holandeses. Domar uma natureza tão exuberante e misteriosa faz com que sejam ativados os mecanismos do reconhecimento, de conformação com uma lógica marcada pela simetria e harmonia dos campos de visão da tela. Domar o selvagem hostil é exercer sobre ele um vetor de força. É pela ótica objetiva que a paisagem e o elemento humano são descritos; ao descrever, o artista utiliza-se de elementos simbólicos que aglutinam a essa paisagem signos dispersos na sua natureza. $O$ personagem primitivo delineia-se frente ao observador da tela, envergando apetrechos que o identificam: cabaça, cesta, pedaços de carne humana, plantas típicas ao seu redor, animais (vide a tela de Albert Eckhout, Índia Tapuia). Ele diz: este sou eu; este é lugar onde moro. A representação objetiva processa-se por meio simbólico, pois estereotipiza o elemento étnico num universo de signos aglutinados no espaço da tela. Mesmo espaço que a letra dos poetas irá habitar na sua referência otimizada da natureza, signo importante para o estrangeiro enquanto elemento identificador dos trópicos.

Esse elemento, de certa forma, dionisíaco, vai predominar nos versos de Manuel de Santa Maria Itaparica (1704-?) em seu canto heróico "Descrição da Ilha de Itaparica":

Cantar procuro, descrever intento.

Em um Heróico verso, e sonoroso,

Aquela que me deu o nascimento,

Pátria feliz, que tive por ditoso:

Ao menos co'este humilde rendimento

Quero mostrar lhe sou afetuoso,

Porque é de ânimo vil e fementido

O que à Pátria não é agradecido.

É com essa intenção de descrever num "Heróico verso, e sonoroso" que a fauna, flora e belezas naturais são descritas e irisadas num campo visual que plasticamente persuade o leitor a compactuar da mesma "sensibilidade ótica". Inserir os trópicos na cultura européia (ibérica) é aproximar o desconhecido do conhecido e acentuar o seu caráter maravilhoso. Assim, o poeta insere no poema personagens mitológicas como participantes desse cenário paradisíaco:

\footnotetext{
Claras as águas são, e transparentes,

Que de si manam copiosas fontes,

Umas regam os vales adjacentes,

Outras descendo vêm dos altos montes;

E quando com seus raios refulgentes,

As doura Febo abrindo os Horizontes,

Tão cristalinas são, que aqui difusa

Parece nasce a fonte da Aretusa.
}

Como participantes da paisagem descrita pelo traço dinâmico das imagens nesta estrofe do poema, ficamos persuadidos a percorrer as singularidades topográficas desse cenário. Do mesmo modo, a tela Panorama Brasileiro, de Frans Post (Fig. 2), traça um caminho de águas pelas linhas diagonais que partem do campo inferior da tela e que ziguezagueando nos levam até o horizonte que se eleva num céu aberto e solar. 


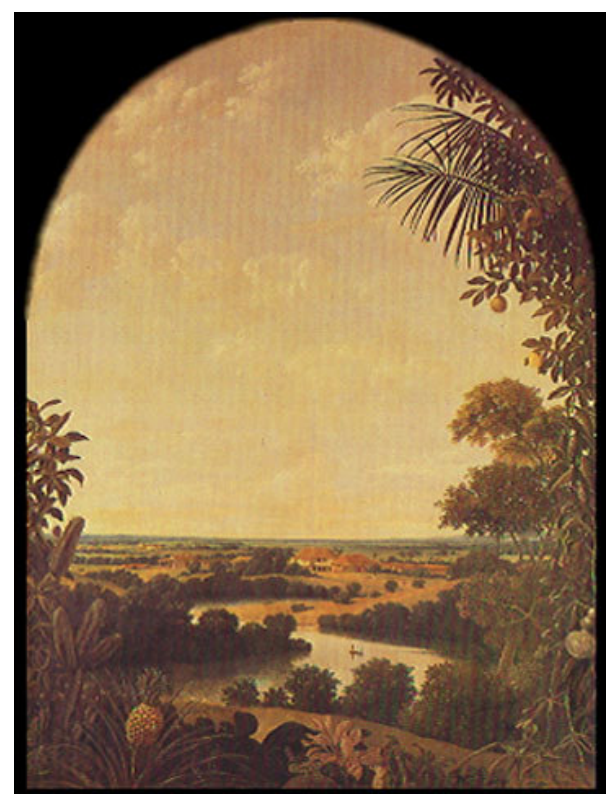

Fig. 2: Frans Post (1612-1680), Panorama Brasileiro, 1652.

Óleo sobre tela, $282,5 \times 210,5 \mathrm{~cm}$.

Amsterdam: Rijksmuseum.

As molduras laterais do cenário estão ornadas com espécies vegetais típicas, assim como o cenário em primeiro plano, que se aproxima do observador. $\mathrm{O}$ olhar que invade a tela representa o maravilhoso diante do espetáculo da natureza selvagem e idílica. Afirma Ana Maria Belluzzo que "Post tornou comum em sua obra obscurecer o primeiro plano e iluminar a região mais distante, de onde fazia irradiar uma luminosidade atmosférica difusa". ${ }^{19}$

Os processos tradutórios da paisagem da América que se apresenta em novas combinações sintático-semânticas aos artistas viajantes durante as primeiras expedições exploratórias fazem-se perceber nas produções pictóricas desses artistas que acompanharam as expedições dos franceses e holandeses no Brasil. Imbuídos de uma linguagem acadêmica e européia na concepção da paisagem, deparam-se com outras formas visuais, com outras combinações sintático-semânticas, que acabam por ocupar hiperbolicamente as telas e a construir o movimento descontínuo do trajeto Europa-América, que veio a inaugurar uma cultura entre nós. Em outras palavras, teríamos uma linguagem acadêmica em termos de pintura, adentrando um território selvagem a céu aberto, que impõe suas cores e sua gente, que protagonizam hiperbólica e simultaneamente o espaço da tela, em forma de crônica. Em adição a esse pensamento, teríamos no olhar estrangeiro duas visões: uma ideológica, temática, que procura pela sensualidade e exotismo apreender o outro; outra estética, que procura realizar a síntese entre o eu e o outro, acentuando o elemento dramático que é a tensão entre as linguagens que lêem a paisagem.

Um recorte da poesia desse mesmo século XVII perfaz pelo olhar barroco a simultaneidade da perspectiva que lê a paisagem, o homem e a cultura. As práticas artísticas tradutórias alimentam-se das coordenadas sintático-semânticas dos aglomerados em trânsito de materiais e processos lúdicos de formalização de respostas aos impulsos que exigem a participação dos sujeitos culturais. $\mathrm{O}$ olhar estrangeiro inaugura o Novo Mundo para a Europa e a desafia a conhecê-lo. O exótico atenua as

${ }^{19}$ BELLUZZO. O Brasil dos viajantes. 
diferenças e exponencia a inscrição do estereótipo entre nós. Precisamos tomar o caminho inverso e partir para a terra, por meio da tela e da letra, para descobrir as raízes dos motivos que nos representaram e nos fizeram protagonistas do diálogo da diferença, paradoxalmente representado pelos artistas do século XVII.

\section{A}

\section{A B STRACT}

This study discusses semiotic aspects which inform the creation of Brazilian culture by means of a process of cultural translation during the voyages of exploration in the 17 th century. The work of traveling artists such as Albert Eckhout and Frans Post is analyzed and compared with the poetry of Baroque authors such as Gregório de Matos, Manuel Botelho de Oliveira and Manuel de Santa Maria Itaparica.

\section{KEYWORDS}

Pictorial and poetic representations of Brazil, the European eye, cultural translation, the Baroque

\section{REFERÊNCIAS}

ÁVILA, Afonso. O lúdico e as projeções do mundo barroco. 2. ed. São Paulo: Perspectiva, 1980. BElluZZO, Ana Maria de Moraes. O Brasil dos viajantes. São Paulo: Fundação Oderbrecht / Metalivros, 1994.

CAMINHA, Pero Vaz de. Carta a El-Rei D. Manuel sobre o achamento do Brasil. In: AGUIAR, Flávio (Org.). Com palmas medida: terra, trabalho e conflito na literatura brasileira. São Paulo: Editora Fundação Perseu Abramo/Boitempo, 1999.

CHAUÍ, Marilena. Brasil: mito fundador e sociedade autoritária. São Paulo: Editora Fundação Perseu Abramo, 2000.

ENCICLOPÉDIA DE ARTES PLÁSTICAS. www.itaucultural.org.br

GIMENEZ, José Carlos. A presença do imaginário medieval no Brasil colonial: descrições dos viajantes. Acta Scientiarum. Maringá, v. 23, n. 1, p. 207-213, 2001.

HOLANDA, Sérgio Buarque de (Org.). Antologia dos poetas brasileiros da fase colonial. São Paulo: Perspectiva, 1979.

HOlANDA, Sérgio Buarque de. Visão do Paraíso. 6. ed. São Paulo: Brasiliense, 1994.

ITAPARICA, Manuel de Santa Maria. Descrição da Ilha de Itaparica. In: HOLANDA, Sérgio Buarque de (Org.). Antologia dos poetas brasileiros da fase colonial. São Paulo: Perspectiva, 1979, p. 141-158.

LAGO, Pedro Corrêa do. Mostra do redescobrimento, 2000, São Paulo: o olhar distante. São Paulo: Fundação Bienal de São Paulo; Associação Brasil 500 anos: Artes Visuais, 2000. LIMA, Lezama. A expressão americana. Trad. Irlemar Chiampi. São Paulo: Brasiliense, 1988. LOTMAN, Yuri. Semiótica de la cultura. Trad. Desiderio Navarro. Madri: Ediciones Cátedra, 1979. 
MATOS, Gregório de. Descreve a Ilha de Itaparica com sua aprazível fertilidade, e louva de caminho ao Capitão Luís Carneiro, homem honrado e liberal, em cuja casa se hospedou. In: MATOS, Gregório de. Poemas Escolhidos. Org. José Miguel WISNIK. São Paulo: Cultrix, s/d, p. 195.

MORIN, Edgar. La Méthode 4 - Les Idées. Paris: Seuil, 1991.

OlIVEIRA, Botelho de. A Ilha de Maré. In: HOLANDA, Sérgio Buarque de (Org.). Antologia dos poetas brasileiros da fase colonial. São Paulo: Perspectiva, 1979, p. 109-118. PEREIRA, Marco Aurélio Monteiro; IEGELSKI, Francine. O Paraíso Terrestre: Os Campos Gerais do Paraná no relato de Auguste de Saint Hilaire. Revista de História Regional, v. 7, n. 1, p. 47-72, Verão 2002.

STADEN, Hans. A verdadeira história dos selvagens, nus, ferozes devoradores de homens. Trad. Pedro Süssekind. Rio de Janeiro: Dantes, 1999.

THEODORO, Janice. América barroca. Rio de Janeiro: Editora Nova Fronteira; São Paulo: EDUSP, 1992.

THEVET, André. As singularidades da França Antártica. Trad. Eugênio Amado. São Paulo: EDUSP, 1978.

VENTURA, Roberto. País tropical: a natureza como pátria. Revista Remate de Males. Campinas, v. 7, p. 27-38, 1987. 